\title{
Influence of folate status on genomic DNA methylation in colonic mucosa of subjects without colorectal adenoma or cancer
}

\author{
M Pufulete ${ }^{*, 1}$, R Al-Ghnaniem ${ }^{2}$, JA Rennie ${ }^{2}$, P Appleby ${ }^{3}$, N Harris ${ }^{4}$, S Gout $^{4}$, PW Emery' and TA Sanders' \\ 'Nutritional Sciences Research Division, King's College London, Franklin Wilkins Building, I 50 Stamford Street, London SEI 9NH, UK; ${ }^{2}$ Department of \\ Surgery, King's College Hospital, Denmark Hill, London SE5 9RS, UK; ${ }^{3}$ Cancer Research UK Epidemiology Unit, The Radcliffe Infirmary, Oxford OX2 6HE, \\ UK; ${ }^{4}$ LGC Limited, Queens' Road, Teddington, Middlesex TWI I OLY, UK
}

\begin{abstract}
DNA hypomethylation may increase the risk of colorectal cancer. The main aim of this study was to assess the influence of folate status (serum and erythrocyte folate and plasma homocysteine concentrations) on DNA methylation. Methylenetetrahydrofolate reductase (MTHFR 677C $\rightarrow$ T and I298A $\rightarrow$ C), methionine synthase (MS 2756A $\rightarrow$ G) and cystathionine synthase (CBS 844ins68) polymorphisms were measured to account for potential confounding effects on folate status and DNA methylation. A total of 68 subjects (33 men and 35 women, 36-78 years) free from colorectal polyps or cancer were recruited in a cross-sectional study. Tissue biopsies were obtained at colonoscopy for the determination of DNA methylation in colonic mucosa using an in vitro radiolabelled methyl acceptance assay. Serum and erythrocyte folate were inversely correlated with plasma homocysteine $(r=-0.573, P<0.00 \mathrm{I}$ and $r=-0.307, P=0.0 \mathrm{I}$ respectively) and DNA hypomethylation in colonic mucosa $(r=-0.3 \mathrm{I} \mathrm{I}, P=0.0 \mathrm{I}$ and $r=-0.356, P=0.03)$. After adjusting for gender, age, body mass index, smoking and genotype, there were weak negative associations between serum and erythrocyte folate and colonic DNA hypomethylation $(P=0.07$ and $P=0.08$, respectively). British Journal of Cancer (2005) 92, 838-842. doi: I0.1038/sj.bjc.6602439 www.bjcancer.com
\end{abstract}

Published online 22 February 2005

(c) 2005 Cancer Research UK

Keywords: folate; homocysteine; DNA methylation; colorectal cancer; genotype; MTHFR; MS; CBS

A low dietary intake of folate has been associated with increased risk of colorectal adenoma and cancer in prospective cohort (Giovannucci et al, 1993; Giovannucci et al, 1995; Giovannucci et al, 1998; Terry et al, 2002) and case-control (Benito et al, 1991; Benito et al, 1993; Tseng et al, 1996; Keku et al, 2002; Boyapati et al, 2004) studies. Furthermore, low serum (Bird et al, 1995; Kato et al, 1999) and erythrocyte folate concentrations (Lashner, 1993; Bird et al, 1995; Paspatis et al, 1995) have been reported to be associated with the development of adenoma or cancer.

Hypomethylation of DNA induced by a lack of folate may predispose to genetic defects associated with the development of neoplasia (Molloy et al, 2002). The methylation cycle maintains the level of the methyl donor $S$-adenosylmethionine (SAM) in cells. The methyl group is provided to DNA through SAM by methyltransferases, which vary according to cell type, and the product of the reaction is $S$-adenosylhomocysteine (SAH). This is immediately hydrolysed to homocysteine and adenosine. The homocysteine can then be either catabolised through cystathionine synthase (CBS) to pyruvate and used for energy or it can be used by the enzyme methionine synthase (MS) for recycling back to methionine and SAM. Methionine synthase has a requirement for a folate cofactor, 5-methyltetrahydrofolate. An inadequate supply of folate results in elevations in the plasma and cellular concentrations of homocysteine. This in turn causes an elevation of $\mathrm{SAH}$, which is a potent inhibitor of all methyltransferase enzymes. Such inhibition, it is suggested, would impair the methylation of DNA,

*Correspondence: Dr M Pufulete; E-mail: maria.pufulete@kcl.ac.uk Received 18 November 2004; revised 10 January 2005; accepted I I January 2005; published online 22 February 2005 leading to changes in normal patterns of DNA methylation that regulate gene expression.

Hypomethylation at critical sites is associated with oncogene activation and tumorigenesis (Sharrard et al, 1992), while hypermethylation of the normally unmethylated $\mathrm{CpG}$ islands in the promoter regions of some tumour suppressor genes prevents transcription and promotes tumorigenesis (Issa et al, 1994; Hiltunen et al, 1997; Iacopetta et al, 1997).

Decreased genomic DNA methylation has been reported in colorectal tumour tissue (Feinberg and Vogelstein, 1983; Goelz et $a l, 1985)$ and normal-appearing colonic mucosa from individuals with cancer (Cravo et al, 1994). A recent study suggested that DNA hypomethylation in normal-appearing colonic mucosa is associated with low folate status and increased risk of colorectal neoplasia (Pufulete et al, 2003). However, no studies have investigated the relationship between DNA methylation in colonic mucosa and folate status in subjects without colorectal adenoma or cancer.

Several common polymorphisms of the remethylating enzymes methyltetrahydrofolate reductase (MTHFR), methionine synthase (MS) and cystathionine synthase (CBS) have been identified. The MTHFR $677 \mathrm{C} \rightarrow \mathrm{T}$ mutation is associated with increased turnover of folate and elevated plasma homocysteine concentration. Two studies suggested that leucocyte DNA is hypomethylated in individuals with low folate status and homozygous for the MTHFR $677 \mathrm{C} \rightarrow \mathrm{T}$ mutation (Stern et al, 2000; Friso et al, 2002). Furthermore, in a recent folate depletion-repletion study, young women carrying the MTHFR 677 TT genotype had a greater increase in leucocyte DNA methylation following repletion with folate than those who did not carry the mutation (Shelnutt et al, 2004). The CBS gene has a variant, 844ins68, which has been linked 
with decreased plasma homocysteine concentration and thus may protect against hypomethylation (Shannon et al, 2002). Homozygotes for the MTHFR $677 \mathrm{C} \rightarrow \mathrm{T}$ and MS $2756 \mathrm{~A} \rightarrow \mathrm{G}$ polymorphisms have been found to have a lower risk of colorectal cancer (Chen et al, 1996; Ma et al, 1999), but only in individuals with adequate folate status and/or low alcohol intake. However, under conditions of low folate status, risk of colorectal neoplasia may be higher in individuals homozygous for the MTHFR $677 \mathrm{C} \rightarrow \mathrm{T}$ mutation (Tseng et al, 1996; Levine et al, 2000; Ulvik et al, 2001; Boyapati et al, 2004). A recent study in Japanese individuals with cancer has shown that the MTHFR $677 \mathrm{C} \rightarrow \mathrm{T}$ and $1298 \mathrm{~A} \rightarrow \mathrm{C}$ mutations were linked with promoter hypermethylation in the cancer tissue (Oyama et al, 2004). Furthermore, patients who were homozygous for the MTHFR $677 \mathrm{C} \rightarrow \mathrm{T}$ mutation had significantly lower concentrations of folate in their tumour tissue (Kawakami et al, 2003). To date, no studies have investigated the effect of genotype on genomic DNA methylation status in healthy colonic mucosa.

The aim of the present study was to assess the influence of folate status on DNA methylation in colonic mucosa in subjects without colorectal adenoma or cancer. Common polymorphisms of the remethylating enzymes were measured to account for potential confounding effects of genotype on folate status and DNA methylation.

\section{MATERIALS AND METHODS}

\section{Subjects}

Subjects were patients referred for colonoscopy at the Department of Colorectal Surgery, King's College Hospital, London, UK. Exclusion criteria included a previous or current diagnosis of cancer or colorectal polyps, a strong family history of colorectal cancer or adenomatous polyposis coli, inflammatory bowel disease and current or past history of gluten-sensitive enteropathy, clinical and/or laboratory evidence of intestinal malabsorption, pregnancy, alcoholism, anaemia (haemoglobin concentration $<11.5 \mathrm{~g} \mathrm{dl}^{-1}$ for women and $<12.0 \mathrm{~g} \mathrm{dl}^{-1}$ for men), low serum $B_{12}$ concentration $\left(<180 \mathrm{ngl}^{-1}\right)$ and use of medication known to antagonise the metabolism of folate. Subjects were eligible for inclusion in the study if they showed no abnormality on full colonoscopy. Rectal bleeding was attributable to the presence of haemorrhoids in subjects referred for colonoscopy with this symptom. Written consent was obtained from all subjects.

Prior to the colonoscopy, a fasting venous blood sample was collected using the vacutainer technique. Blood was collected into EDTA vacutainers for full blood count, plasma homocysteine and erythrocyte folate assays and into vacutainers containing no anticoagulant for determination of serum vitamin $B_{12}$ and folate concentrations and liver function tests. For plasma homocysteine, the vacutainers were chilled on ice and plasma was separated within $2 \mathrm{~h}$ of collection and frozen at $-70^{\circ} \mathrm{C}$. Weight and height were recorded and information on smoking habits, physical activity levels, current medication and supplement use was gathered before colonoscopy. During colonoscopy, three mucosal biopsies were removed from the rectum (about $12 \mathrm{~cm}$ from the anal verge) and immediately snap frozen in liquid nitrogen. All patients had prepared for the colonoscopy by taking orally administered colonic lavage solution (KleanPrep ${ }^{\mathbb{R}}$, Norgine, Harefield, UK).

At 1 week after the colonoscopy, subjects completed a previously validated short food frequency questionnaire (Pufulete et al, 2002) to assess habitual intake of alcohol and folate. It was decided that the FFQ should not be administered at the time of colonoscopy, as subjects had been fasting and taking bowel preparation and were anxious about the procedure, which may have affected their response. The protocol for the study was approved by the Research
Ethics Committees at King's College Hospital and King's College London.

\section{Laboratory methods}

Fasting venous blood samples were obtained prior to the colonoscopy for determination of serum and erythrocyte folate concentrations, plasma homocysteine and MTHFR $677 \mathrm{C} \rightarrow \mathrm{T}$ and $1298 \mathrm{~A} \rightarrow \mathrm{C}$, MS $2756 \mathrm{~A} \rightarrow \mathrm{G}$ and CBS 844ins68 polymorphisms. Rectal biopsies of normal-appearing mucosa for the determination of genomic DNA methylation were obtained during the colonoscopy.

The laboratory methods used to analyse serum and erythrocyte folate concentrations, plasma homocysteine, genomic DNA methylation and gene polymorphisms have been described in detail elsewhere (Pufulete et al, 2003). Genomic DNA methylation was determined in colonic mucosa using an in vitro methyl acceptance assay (Balaghi and Wagner, 1993). In this assay, a decrease in methyl group incorporation in DNA indicates an increase in methylation status. Within run and between run, CVs were 5.3 and $8.9 \%$, respectively.

\section{Statistics}

Analyses were performed using Intercooled Stata (version 6.0. for Windows, Stata Corporation, USA). Logarithmic transformations were used for erythrocyte folate, serum vitamin $B_{12}$ and plasma homocysteine as the distribution of these variables was positively skewed. Analysis of variance was used to compare folate intake, serum and erythrocyte folate, plasma homocysteine and genomic DNA methylation for each genotype, after adjusting for gender, age, body mass index and smoking. The relationships between continuous variables were examined using the Pearson and Spearman correlation coefficients.

The relationships between markers of folate status (dietary folate intake, serum and erythrocyte folate) and each of plasma homocysteine and genomic DNA methylation in colonic mucosa were analysed by multiple linear regression with adjustment for gender, age, body mass index, smoking and genotype.

\section{RESULTS}

A total of 68 subjects ( 33 men and 35 women), aged 36-78 years, were found to be eligible for the study; their details are shown in Table 1 . Blood counts and serum vitamin $B_{12}$ concentrations were all within the normal laboratory range.

Table 2 shows mean values of folate intake, serum and erythrocyte folate, plasma homocysteine concentrations and $\left[{ }^{3} \mathrm{H}\right]$ methyl incorporation in colonic DNA according to the genotypes, adjusted for gender, age, BMI and smoking. Allele frequencies for the MTHFR $677 \mathrm{C} \rightarrow \mathrm{T}$, MTHFR $1298 \mathrm{~A} \rightarrow \mathrm{C}$, MS $2756 \mathrm{~A} \rightarrow \mathrm{G}$ and CBS 844ins68 mutations were $44,35,40$ and $25 \%$, respectively. There was heterogeneity between the means for each of serum folate and plasma homocysteine and alleles of the MTHFR $677 \mathrm{C} \rightarrow \mathrm{T}$ polymorphism $(P=0.007$ and $P=0.0002$, respectively), and between $\left[{ }^{3} \mathrm{H}\right]$ methyl incorporation in colonic DNA and alleles of the MS $2756 \mathrm{~A} \rightarrow \mathrm{G}$ polymorphism $(P=0.05)$. The mean serum folate concentration was $45 \%$ lower and the mean plasma homocysteine concentration $110 \%$ higher in subjects homozygous for the $\mathrm{T}$ allele of the MTHFR $677 \mathrm{C} \rightarrow \mathrm{T}$ genotype than in those homozygous for the $\mathrm{C}$ allele.

$\left[{ }^{3} \mathrm{H}\right]$ methyl incorporation in colonic DNA was lower in subjects carrying the $\mathrm{G}$ allele for the MS $2756 \mathrm{~A} \rightarrow \mathrm{G}$ mutation (by 18 and $28 \%$ in subjects homozygous (GG) and heterozygous (AG), respectively) than in those without the mutation (AA). There was no influence on $\left[{ }^{3} \mathrm{H}\right]$ methyl incorporation in colonic DNA 
Table I Subject characteristics by gender

\begin{tabular}{|c|c|c|c|}
\hline & Men $(n=33)$ & Women $(n=35)$ & All $(n=68)$ \\
\hline Body mass index $\left(\mathrm{kg} \mathrm{m}^{-2}\right)^{\mathrm{a}}$ & $26.9 \pm 4.1$ & $26.5 \pm 4.9$ & $26.7 \pm 4.5$ \\
\hline Hemoglobin $\left(g \mathrm{gl}^{-1}\right)^{\mathrm{e}}$ & $14.5(\mid 2.2-17.2)$ & $13.8(\mid 1.9-16.9)$ & $13.8(\mid 1.9-17.2)$ \\
\hline Serum folate $\left(\left.\mu \mathrm{g}\right|^{-1}\right)^{\mathrm{a}}$ & $8.1 \pm 3.7$ & $8.3 \pm 3.2$ & $8.2 \pm 3.4$ \\
\hline Erythrocyte folate $\left(\mu \mathrm{g}^{-1}\right)^{\mathrm{e}}$ & $289(143-645)$ & $278(110-1040)$ & $286(110-1040)$ \\
\hline$\left[{ }^{3} \mathrm{H}\right]$ methyl incorporation in colonic DNA (Bq $\left.\mu \mathrm{g} \mathrm{DNA}^{-1}\right)^{\mathrm{a}}$ & $375 \pm 200$ & $413 \pm 20 I^{f}$ & $394 \pm 200^{8}$ \\
\hline \multicolumn{4}{|l|}{ Smoking (n (\%)) } \\
\hline Current smoker & $12(36)$ & $9(26)$ & $2 \mid(3 \mid)$ \\
\hline Nonsmoker & $21(64)$ & $26(74)$ & $47(69)$ \\
\hline
\end{tabular}

${ }^{a}$ Arithmetic mean \pm s.d. ${ }^{b}(n=29) \cdot{ }^{c}(n=32) \cdot{ }^{d}(n=61) .{ }^{e}$ Median (with range in parentheses). ${ }^{f}(n=34) \cdot{ }^{g}(n=67)$.

Table 2 Mean folate intake, serum folate, erythrocyte folate, plasma homocysteine and $\left[{ }^{3} \mathrm{H}\right]$ methyl incorporation in colonic DNA for all subjects and according to MTHFR, MS and CBS genotypes

\begin{tabular}{|c|c|c|c|c|c|c|}
\hline & $n(\%)$ & $\begin{array}{c}\begin{array}{c}\text { Folate intake } \\
\left(\mu \mathrm{g} \mathrm{day}^{-1}\right)^{\mathrm{a}}\end{array} \\
\text { Mean }(95 \% \mathrm{Cl})^{\mathrm{c}}\end{array}$ & $\begin{array}{c}\text { Serum folate } \\
\left(\mu \mathrm{g} \mathrm{I}^{-1}\right) \\
\text { Mean }(95 \% \mathrm{Cl})^{\mathrm{c}}\end{array}$ & $\begin{array}{c}\text { Erythrocyte } \\
\text { folate }\left(\mu \mathrm{gl}^{-1}\right) \\
\text { Mean }(95 \% \mathrm{Cl})^{\mathrm{d}}\end{array}$ & $\begin{array}{c}\text { Plasma } \\
\text { homocysteine } \\
\left(\mu \mathrm{mol} \mathrm{L}^{-1}\right) \\
\text { Mean }(95 \% \mathrm{Cl})^{\mathrm{d}}\end{array}$ & $\begin{array}{c}{\left[{ }^{3} \mathrm{H}\right] \text { methyl }} \\
\text { incorporation in } \\
\text { colonic DNA } \\
\left(\mathrm{Bq} \mu \mathrm{g} \text { DNA }{ }^{-1}\right)^{b} \\
\text { Mean }(95 \% \mathrm{Cl})^{\mathrm{c}}\end{array}$ \\
\hline All & $68(100)$ & $359(329-390)$ & $8.2(7.5-9.0)$ & $296(27 \mid-323)$ & $10.9(9.9-12.0)$ & $394(352-439)$ \\
\hline \multicolumn{7}{|c|}{ MTHFR 677C $\rightarrow T$} \\
\hline \multirow[t]{2}{*}{$\pi T$} & $6(9)$ & $362(260-464)$ & $5.1(2.5-7.8)$ & $318(230-438)$ & $20.8(15.4-28.3)$ & $447(291-603)$ \\
\hline \multirow{2}{*}{\multicolumn{7}{|c|}{ MTHFR $1298 \mathrm{~A} \rightarrow \mathrm{C}$}} \\
\hline & & & & & & \\
\hline$A A$ & $44(65)$ & $355(315-394)$ & $8.1(7.1-9.2)$ & $301(268-337)$ & $10.8(9.6-12.2)$ & $408(352-464)$ \\
\hline$A C$ & $22(32)$ & $365(3||-4 \mid 8)$ & $8.3(6.8-9.8)$ & $291(247-344)$ & $11.5(9.6-13.8)$ & $389(309-468)$ \\
\hline CC & $2(3)$ & $395(226-565)$ & $9.9(5.1-14.7)$ & $244(143-417)$ & $7.6(4.3-13.4)$ & $209(47-465)$ \\
\hline GG & $8(12)$ & $390(296-485)$ & $8.2(5.7-10.7)$ & $304(230-401)$ & $10.6(7.8-14.3)$ & $359(230-489)$ \\
\hline & & $P=0.86$ & $P=0.94$ & $P=0.47$ & $P=0.81$ & $P=0.05$ \\
\hline \multicolumn{7}{|c|}{ CBS 844ins68 } \\
\hline Wild type & $51(75)$ & $355(321-390)$ & $8.3(7.3-9.2)$ & $286(258-317)$ & $10.8(9.6-12.0)$ & $404(352-455)$ \\
\hline \multirow[t]{2}{*}{844 ins68 } & $17(25)$ & $372(310-435)$ & $8.2(6.5-9.9)$ & $328(273-395)$ & $11.4(9.3-14.0)$ & $372(282-463)$ \\
\hline & & $P=0.60$ & $P=0.96$ & $P=0.22$ & $P=0.61$ & $P=0.57$ \\
\hline
\end{tabular}

MTHFR = methylenetetrahydrofolate reductase; $M S=$ methionine synthase; $C B S=$ cystathionine synthase. ${ }^{a}(n=61) .{ }^{b}(n=67) .{ }^{c}$ Arithmetic or ${ }^{d}$ Geometric means $($ with $95 \%$ C in parentheses) adjusted for gender, age, BMI and smoking. The $P$-values relate to tests of heterogeneity between the means arising from the relevant $F$-test statistic in the analysis of variance table.

of the MTHFR $(677 \mathrm{C} \rightarrow \mathrm{T}$ and $1298 \mathrm{~A} \rightarrow \mathrm{C})$ and CBS 844ins68 genotypes.

Smokers had higher mean $\left[{ }^{3} \mathrm{H}\right]$ methyl incorporation in colonic DNA than nonsmokers (490 (s.d. 193) Bq $\mu \mathrm{g} \mathrm{DNA}^{-1}$ vs 353 (s.d. 190) $\mathrm{Bq} \mu \mathrm{g} \mathrm{DNA}^{-1}, P=0.01$ ), and lower folate intakes (303 (s.d. 134) $\mu$ g day $^{-1}$ vs 380 (s.d. 113) $\mu$ g day $^{-1}, P=0.03$ ) and serum folate concentrations (6.9 (s.d. 3.2) $\mu \mathrm{gl}^{-1}$ vs 8.8 (s.d. 3.4) $\mu \mathrm{gl}^{-1}$, $P=0.03$ )

Folate intake was positively correlated with both serum folate $(r=0.515, \quad P<0.001)$ and erythrocyte folate concentrations $(r=0.473, P<0.001)$. Plasma homocysteine concentration was positively correlated with age $(r=0.323, P=0.007)$ and negatively correlated with folate intake $(r=-0.284, P=0.027)$, serum folate $(r=-0.573, P<0.001)$, erythrocyte folate $(r=-0.307, P=0.01)$ and serum vitamin $\mathrm{B}_{12}$ concentrations $(r=-0.402, P=0.001)$. Multiple linear regression analysis with plasma homocysteine concentration as the dependent variable showed that gender $(P=0.05)$, age $(P=0.05)$, serum folate $(P=0.001)$, serum vitamin $\mathrm{B}_{12}(P=0.002)$ and MTHFR 677C $\rightarrow$ T polymorphism (with higher homocysteine concentration in subjects homozygous for the $\mathrm{T}$ 
allele, $P=0.002$ ) were each associated with plasma homocysteine, independent of body mass index, smoking and other genotypes.

$\left[{ }^{3} \mathrm{H}\right]$ methyl incorporation in colonic DNA was positively correlated with age $(r=0.260, P=0.03)$ and plasma homocysteine $(r=0.256, P=0.04)$ and negatively correlated with serum folate $(r=-0.311, P=0.01)$, erythrocyte folate $(r=-0.356, P=0.003)$ and serum vitamin $\mathrm{B}_{12}$ concentrations $(r=-0.218, P=0.08)$. There was no association between $\left[{ }^{3} \mathrm{H}\right]$ methyl incorporation in colonic DNA and alcohol intake $(r=0.013, P=0.92)$. Multiple linear regression analysis with $\left[{ }^{3} \mathrm{H}\right]$ methyl incorporation in colonic DNA as the dependent variable showed a weak positive association with smoking $(P=0.05)$, and weak negative associations with each of serum folate $(P=0.07)$ and erythrocyte folate $(P=0.08)$, independent of gender, age, body mass index and all genotypes. No other associations were noted.

\section{DISCUSSION}

The aim of this study was to determine the contribution of folate status to genomic DNA methylation in colonic mucosa in subjects with no colorectal abnormalities. DNA methylation was determined by measuring $\left[{ }^{3} \mathrm{H}\right]$ methyl incorporation in DNA. Thus, an increase in $\left[{ }^{3} \mathrm{H}\right]$ methyl incorporation reflects a decrease in methylation. The $\left[{ }^{3} \mathrm{H}\right]$ methyl acceptance assay is indirect and only semiquantitative; a known limitation of this assay is that damaged DNA templates (DNA adducts, strand breaks and abasic sites) can accept methyl groups in the methylase reaction and may therefore give a false positive indication of hypomethylation. Despite this drawback, there was a trend for an association between DNA hypomethylation, smoking and folate status. It is well known that the dietary habits of smokers differ from those of nonsmokers, and in the present study the dietary intake of folate was lower in the smokers. However, the effects of smoking and folate appeared to be independent predictors of hypomethylation. A limitation of the present study is that we did not measure colonic mucosal folate concentrations. DNA methylation was not associated with alcohol intake, which is known to have negative effects on methyl metabolism and is associated with increased risk of colorectal cancer (Chen et al, 1996). However, median alcohol intake in this group of individuals was relatively low. A wider range of intakes would need to be considered before firm conclusions on the relationship between DNA methylation and alcohol intake can be drawn.

Common polymorphisms in remethylating enzymes were measured to adjust for possible confounding influences on DNA methylation and folate status. The frequencies of the mutated alleles for MTHFR $677 \mathrm{C} \rightarrow \mathrm{T}$ and $1298 \mathrm{~A} \rightarrow \mathrm{C}$ were 44 and $35 \%$, respectively, which were similar to those reported in other Caucasian populations: $35 \%$ for MTHFR $677 \mathrm{C} \rightarrow \mathrm{T}$ (Frosst et al, 1995; Gudnason et al, 1998) and 30\% for MTHFR 1298A $\rightarrow$ C (van der Put et al, 1998). Allele frequencies for MS 2756A $\rightarrow \mathrm{G}$ and CBS

\section{REFERENCES}

Balaghi M, Wagner C (1993) DNA methylation in folate deficiency: use of CPG methylase. Biochem Biophys Res Commun 193: 1184-1190

Benito E, Cabeza E, Moreno V, Obrador A, Bosch FX (1993) Diet and colorectal adenomas: a case-control study in Majorca. Int J Cancer 55: $213-219$

Benito E, Stiggelbout A, Bosch FX, Obrador A, Kaldor J, Mulet M, Munoz N (1991) Nutritional factors in colorectal cancer risk: a case-control study in Majorca. Int J Cancer 49: 161-167

Bird CL, Swendseid ME, Witte JS, Shikany JM, Hunt IF, Frankl HD, Lee ER, Longnecker MP, Haile RW (1995) Red cell and plasma folate, folate consumption, and the risk of colorectal adenomatous polyps. Cancer Epidemiol Biomarkers Prev 4: 709-714
844 ins68 were somewhat higher (40 and $25 \%$, respectively) in the present study compared with $20 \%$ (Leclerc et al, 1996) and $8 \%$ (Tsai et al, 1999), respectively, reported in other Caucasian populations. Individuals carrying the $G$ allele for the MS $2756 \mathrm{~A} \rightarrow \mathrm{G}$ genotype had higher genomic DNA methylation status in colonic mucosa, although DNA methylation was slightly higher in heterozygotes (AG) than in those homozygous for the $G$ allele (GG). This finding lends some support to the observation of an inverse association between the MS $2756 \mathrm{~A} \rightarrow \mathrm{G}$ genotype and colorectal cancer risk (Ma et al, 1999). Several studies have also shown that plasma homocysteine concentrations are lower in subjects carrying the $G$ allele (Harmon et al, 1999; Chen et al, 2001). This may indicate some benefit associated with this polymorphism, although to date the functional consequences for enzyme activity of the MS $2756 \mathrm{~A} \rightarrow \mathrm{G}$ genotype are unclear.

In the present study, we were unable to demonstrate any influence of the MTHFR $677 \mathrm{C} \rightarrow \mathrm{T}$ and MTHFR $1298 \mathrm{~A} \rightarrow \mathrm{C}$, and CBS 844ins68 genotypes on DNA methylation but the number of subjects homozygous for the two MTHFR polymorphisms or carrying the CBS 844ins68 was small. A much larger and appropriately designed study would be required to investigate the effects of common genetic variations on DNA methylation and to assess any gene-gene interactions. However, the findings of the multiple regression analysis suggest that folate status may be a stronger determinant of colonic DNA methylation than genotype. In colorectal tumours, genomic DNA hypomethylation is often associated with altered methylation patterns in CpG islands in the promoter regions of critical genes. Promoter hyper- and hypomethylation has been shown to silence tumour suppressor genes (Hiltunen et al, 1997) and activate oncogenes (Sharrard et al, 1992), respectively. Future studies should investigate the possible link between folate and $\mathrm{CpG}$ island methylation, particularly since there is evidence suggesting that $\mathrm{CpG}$ island hypermethylation in critical genes (e.g., oestrogen receptor, ER; mismatch repair, MLH1) occurs in normal colonic mucosa (Issa et al, 1994; Nakagawa et al, 2001).

In conclusion, this study suggests that folate status may be a determinant of the methylation status of genomic DNA in colonic mucosa and provides evidence for a plausible mechanism through which folate may influence risk of colorectal cancer. However, the small sample size precludes any definitive conclusions to be drawn. The findings of this pilot study require confirmation in a larger prospective cohort study.

\section{ACKNOWLEDGEMENTS}

We gratefully acknowledge Dr Roy Sherwood and staff at the Department of Clinical Biochemistry, King's College Hospital, for conducting the serum and erythrocyte folate and plasma homocysteine assays.
Boyapati SM, Bostick RM, McGlynn KA, Fina MF, Roufail WM, Geisinger KR, Hebert JR, Coker A, Wargovich M (2004) Folate intake, MTHFR C677T polymorphism, alcohol consumption, and risk for sporadic colorectal adenoma (United States). Cancer Causes Control 15: 493-501

Chen J, Giovannucci E, Kelsey K, Rimm EB, Stampfer MJ, Colditz GA, Spiegelman D, Willett WC, Hunter DJ (1996) A methylenetetrahydrofolate reductase polymorphism and the risk of colorectal cancer. Cancer Res 56: $4862-4864$

Chen J, Stampfer MJ, Ma J, Selhub J, Malinow MR, Hennekens CH, Hunter DJ (2001) Influence of a methionine synthase (D919G) polymorphism on plasma homocysteine and folate levels and relation to risk of myocardial infarction. Atherosclerosis 154: 667-672 
Cravo M, Fidalgo P, Pereira AD, Gouveia-Oliveira A, Chaves P, Selhub J, Mason JB, Mira FC, Leitao CN (1994) DNA methylation as an intermediate biomarker in colorectal cancer: modulation by folic acid supplementation. Eur J Cancer Prev 3: $473-479$

Feinberg AP, Vogelstein B (1983) Hypomethylation distinguishes genes of some human cancers from their normal counterparts. Nature 301: 89-92

Friso S, Choi SW, Dolnikowski GG, Selhub J (2002) A method to assess genomic DNA methylation using high-performance liquid chromatography/electrospray ionization mass spectrometry. Anal Chem 74: $4526-$ 4531

Frosst P, Blom HJ, Milos R, Goyette P, Sheppard CA, Matthews RG, Boers GJ, den Heijer M, Kluijtmans LA, van den Heuvel LP (1995) A candidate genetic risk factor for vascular disease: a common mutation in methylenetetrahydrofolate reductase. Nat Genet 10: 111-113

Giovannucci E, Rimm EB, Ascherio A, Stampfer MJ, Colditz GA, Willett WC (1995) Alcohol, low-methionine-low-folate diets, and risk of colon cancer in men. J Natl Cancer Inst 87: 265-273

Giovannucci E, Stampfer MJ, Colditz GA, Hunter DJ, Fuchs C, Rosner BA, Speizer FE, Willett WC (1998) Multivitamin use, folate, and colon cancer in women in the Nurses' Health Study. Ann Intern Med 129: 517-524

Giovannucci E, Stampfer MJ, Colditz GA, Rimm EB, Trichopoulos D, Rosner BA, Speizer FE, Willett WC (1993) Folate, methionine, and alcohol intake and risk of colorectal adenoma. J Natl Cancer Inst 85: $875-884$

Goelz SE, Vogelstein B, Hamilton SR, Feinberg AP (1985) Hypomethylation of DNA from benign and malignant human colon neoplasms. Science 228: $187-190$

Gudnason V, Stansbie D, Scott J, Bowron A, Nicaud V, Humphries S (1998) C677T (thermolabile alanine/valine) polymorphism in methylenetetrahydrofolate reductase (MTHFR): its frequency and impact on plasma homocysteine concentration in different European populations. EARS Group. Atherosclerosis 136: $347-354$

Harmon DL, Shields DC, Woodside JV, McMaster D, Yarnell JW, Young IS, Peng K, Shane B, Evans AE, Whitehead AS (1999) Methionine synthase D919G polymorphism is a significant but modest determinant of circulating homocysteine concentrations. Genet Epidemiol 17: 298-309

Hiltunen MO, Alhonen L, Koistinaho J, Myohanen S, Paakkonen M, Marin S, Kosma VM, Janne J (1997) Hypermethylation of the APC (adenomatous polyposis coli) gene promoter region in human colorectal carcinoma. Int J Cancer 70: 644-648

Iacopetta BJ, Harmon D, Spagnolo DV, House AK, Kay PH (1997) Hypermethylation of the Myf-3 gene in human colorectal cancer. Anticancer Res 17: 429-432

Issa JP, Ottaviano YL, Celano P, Hamilton SR, Davidson NE, Baylin SB (1994) Methylation of the oestrogen receptor CpG island links ageing and neoplasia in human colon. Nat Genet 7: 536-540

Kato I, Dnistrian AM, Schwartz M, Toniolo P, Koenig K, Shore RE, Akhmedkhanov A, Zeleniuch-Jacquotte A, Riboli E (1999) Serum folate, homocysteine and colorectal cancer risk in women: a nested casecontrol study. Br J Cancer 79: $1917-1922$

Kawakami K, Ruszkiewicz A, Bennett G, Moore J, Watanabe G, Iacopetta B (2003) The folate pool in colorectal cancers is associated with DNA hypermethylation and with a polymorphism in methylenetetrahydrofolate reductase. Clin Cancer Res 9: 5860-5865

Keku T, Millikan R, Worley K, Winkel S, Eaton A, Biscocho L, Martin C, Sandler R (2002) 5,10-Methylenetetrahydrofolate reductase codon 677 and 1298 polymorphisms and colon cancer in African Americans and whites. Cancer Epidemiol Biomarkers Prev 11: 1611 - 1621

Lashner BA (1993) Red blood cell folate is associated with the development of dysplasia and cancer in ulcerative colitis. J Cancer Res Clin Oncol 119: 549-554

Leclerc D, Campeau E, Goyette P, Adjalla CE, Christensen B, Ross M, Eydoux P, Rosenblatt DS, Rozen R, Gravel RA (1996) Human methionine synthase: cDNA cloning and identification of mutations in patients of the cblG complementation group of folate/cobalamin disorders. Hum Mol Genet 5: $1867-1874$
Levine AJ, Siegmund KD, Ervin CM, Diep A, Lee ER, Frankl HD, Haile RW (2000) The methylenetetrahydrofolate reductase $677 \mathrm{C} \rightarrow$ T polymorphism and distal colorectal adenoma risk. Cancer Epidemiol Biomarkers Prev 9: $657-663$

Ma J, Stampfer MJ, Christensen B, Giovannucci E, Hunter DJ, Chen J, Willett WC, Selhub J, Hennekens CH, Gravel R, Rozen R (1999) A polymorphism of the methionine synthase gene: association with plasma folate, vitamin B12, homocyst(e)ine, and colorectal cancer risk. Cancer Epidemiol Biomarkers Prev 8: 825-829

Molloy AM, Mills JL, McPartlin J, Kirke PN, Scott JM, Daly S (2002) Maternal and fetal plasma homocysteine concentrations at birth: the influence of folate, vitamin B12, and the 5,10-methylenetetrahydrofolate reductase $677 \mathrm{C} \rightarrow \mathrm{T}$ variant. Am J Obstet Gynecol 186: 499-503

Nakagawa H, Nuovo GJ, Zervos EE, Martin Jr EW, Salovaara R, Aaltonen LA, de la Chapelle A (2001) Age-related hypermethylation of the 5 region of MLH1 in normal colonic mucosa is associated with microsatellite-unstable colorectal cancer development. Cancer Res 61: $6991-6995$

Oyama K, Kawakami K, Maeda K, Ishiguro K, Watanabe G (2004) The association between methylenetetrahydrofolate reductase polymorphism and promoter methylation in proximal colon cancer. Anticancer Res 24: $649-654$

Paspatis GA, Kalafatis E, Oros L, Xourgias V, Koutsioumpa P, Karamanolis DG (1995) Folate status and adenomatous colonic polyps. A colonoscopically controlled study. Dis Colon Rectum 38: 64-67

Pufulete M, Al Ghnaniem R, Leather AJ, Appleby P, Gout S, Terry C, Emery PW, Sanders TA (2003) Folate status, genomic DNA hypomethylation, and risk of colorectal adenoma and cancer: a case control study. Gastroenterology 124: 1240-1248

Pufulete M, Emery PW, Nelson M, Sanders TA (2002) Validation of a short food frequency questionnaire to assess folate intake. Br J Nutr 87: $383-390$

Shannon B, Gnanasampanthan S, Beilby J, Iacopetta B (2002) A polymorphism in the methylenetetrahydrofolate reductase gene predisposes to colorectal cancers with microsatellite instability. Gut 50: $520-524$

Sharrard RM, Royds JA, Rogers S, Shorthouse AJ (1992) Patterns of methylation of the c-myc gene in human colorectal cancer progression. Br J Cancer 65: 667-672

Shelnutt KP, Kauwell GP, Gregory III JF, Maneval DR, Quinlivan EP, Theriaque DW, Henderson GN, Bailey LB (2004) Methylenetetrahydrofolate reductase $677 \mathrm{C} \rightarrow \mathrm{T}$ polymorphism affects DNA methylation in response to controlled folate intake in young women. J Nutr Biochem 15: 554-560

Stern LL, Mason JB, Selhub J, Choi SW (2000) Genomic DNA hypomethylation, a characteristic of most cancers, is present in peripheral leukocytes of individuals who are homozygous for the C677T polymorphism in the methylenetetrahydrofolate reductase gene. Cancer Epidemiol Biomarkers Prev 9: 849-853

Terry P, Jain M, Miller AB, Howe GR, Rohan TE (2002) Dietary intake of folic acid and colorectal cancer risk in a cohort of women. Int J Cancer 97: $864-867$

Tsai MY, Yang F, Bignell M, Aras O, Hanson NQ (1999) Relation between plasma homocysteine concentration, the 844ins68 variant of the cystathionine beta-synthase gene, and pyridoxal- $5^{\prime}$-phosphate concentration. Mol Genet Metab 67: 352-356

Tseng M, Murray SC, Kupper LL, Sandler RS (1996) Micronutrients and the risk of colorectal adenomas. Am J Epidemiol 144: 1005-1014

Ulvik A, Evensen ET, Lien EA, Hoff G, Vollset SE, Majak BM, Ueland PM (2001) Smoking, folate and methylenetetrahydrofolate reductase status as interactive determinants of adenomatous and hyperplastic polyps of colorectum. Am J Med Genet 101: 246-254

van der Put NM, Gabreels F, Stevens EM, Smeitink JA, Trijbels FJ, Eskes TK, van den Heuvel LP, Blom HJ (1998) A second common mutation in the methylenetetrahydrofolate reductase gene: an additional risk factor for neural-tube defects? Am J Hum Genet 62: 1044-1051 